\title{
Socio-Economic Importance and Livelihood Utilization of Bamboo (Bambusa vulgris) in Imo State Southeast Nigeria
}

\author{
Nwaihu E. C. ${ }^{1}$, Egbuche C. T. ${ }^{1}$, Onuoha G. N. ${ }^{2}$, Ibe A. E. ${ }^{1}$, Umeojiakor A. O. ${ }^{1}$, Chukwu A. O. ${ }^{3}$ \\ ${ }^{1}$ Department of Forestry and Wildlife Technology, Federal University of Technology, Owerri, Imo State Nigeria \\ ${ }^{2}$ Department of chemistry, Federal University of Technology, Owerri, Imo State Nigeria \\ ${ }^{3}$ Department of Agricultural Economics and Extension, Federal University of Technology, Owerri, Imo State Nigeria
}

\author{
Email address: \\ ctoochi@yahoo.co.uk (Egbuche C. T.)
}

\section{To cite this article:}

Nwaihu E. C., Egbuche C. T., Onuoha G. N., Ibe A. E., Umeojiako A. O., Chukwu A. O.. Socio-Economic Importance and Livelihood Utilization of Bamboo (Bambusa vulgris) in Imo State Southeast Nigeria. Agriculture, Forestry and Fisheries. Special Issue: Environment and Applied Science Management in a Changing Global Climate. Vol. 4, No. 3-1, 2015, pp. 81-85. doi: 10.11648/j.aff.s.2015040301.24

\begin{abstract}
The study was conducted in the three Local Government Areas of Mbaise; namely Aboh, Ahiazu and Ezinihitte to assess the socio-economic importance of Bamboo (Bambusa vulgaris) in Mbaise. Respondents for the study were selected from the three Local Government Areas, and each of Local Government produced three Communities to give a total of Nine Communities to give a total of one hundred and eighty (180) respondents. The entire selection was by random and purposive sampling technique. The objectives of the study were to; determine the various uses of bamboo and to ascertain the contribution of bamboo in the present dispensation to the socio-economic well being of the people in the study area. The data were collected using questionnaire, oral interview schedule and field visits. Data collected were analyzed using descriptive statistics such as percentages, frequency distribution table and return on investment (ROI). The result showed that majority (78\%) of the respondents were male, 58\% were between the age of 41-50 years, 76\% were married, 38\% had FSLC education. The result further revealed that 130 of the respondents use bamboo for staking of yams, 164 for erosion control, 168 for watershed while 68 indicated using it for building construction. Equally, 68 stated using it to confer aesthetic beauty on structures, 148 uses it for thatching/fencing and barn construction while an insignificant number (26) use it to construct platform, for goats. The result further revealed that $73 \%$ of the respondents are owners as well as dealers, $29 \%$ are middlemen dealers (Major) while 7\% are middlemen dealers (Minor). Analysis done on return on investment indicated that dealers on bamboo made $92 \mathrm{k}, 82 \mathrm{k}$ and $76 \mathrm{k}$ profit for every naira invested in the business of supply for building, staking of yams and fencing barn construction and thatching respectively. From the foregoing, bamboo contributes in no small measure to employment and income generation in the study area.
\end{abstract}

Keywords: Socio-Economic, Bambusa vulgris Importance, Livelihood, Imo State Nigeria

\section{Introduction}

Bamboo (Bambusa) is a drought resistant perennial woody grass belonging to the group angiosperm and the order monocotyledon. They are in the sub-family of bambusoideae and family poacae Forest composition was assessed in the last century in terms of the commercial value of timber.

Seldom was other forest component considered to have economic value [1]. In the 1900's, when vast area of tropical forests were exploited of timber for local use, bamboos and other non-timber products such as mushrooms snails, wildlife, vegetables of both food and medicinal plant like Gnetum Africana, Vernonia amygdalina, Dennetia tripetalla, Gercina cola, Afriamomu meleguata, Xylopia ethiopic etc, were considered as having no economic value and as such ignored.

Bamboo is the fastest growing timber like substance on earth, growing skyward as fast as $121 \mathrm{~cm}$ in 24 hours period and can also reach maximal growth rate exceeding one meter per hour for short period of time [2]. A Culm can reach its full maturity in a matter of two to three months which makes it one of the forests growing, highest yielding renewable natural Resources [3]. Bamboo reaches maturity in three to five years of growth compared with timber products that take a longer of period 30-50 years to mature [4]. Bamboo is widely distributed in South East, South-South and middle belt of Nigeria based on ecological disposition of these rain forest regions [5]. Here in Nigeria, Bamboo is generally called Indian Bamboo and 
originated from South East Asia [6].

Bamboo has made significant contributions to rural and urban livelihood apart from its ecosystems role. The single most important item of forest product used extensively in the tropical rural communities is bamboo. It plays important role in the environment, including hydrologic cycle, soil conservation and preservation of biodiversity. Bamboos are important resources (renewable resources) of economic welfare and rural development. The socio economic role of Bamboo in particular and forestry in general boils down to poverty alleviation, generation of employment, income and improved standard of living in general. The utilization of bamboo and forest resources by the rural people posses a great potential to the solution of rural poverty, unemployment and backwardness. The forest and its resources (Bamboo) together with the benefits they provide in form of income. Watershed and environmental protection enable the rural people to secure a stable livelihood. Rural people have great skills and are capable of transforming Bamboo and other forest products into simple products which can attract higher prices both within rural and urban markets [7].

In the rural areas bamboo is extensively used in making fencing, planted around ponds as water shed to reduce evaporation, carbon sequestration, making of wooden gong, used as staking materials for yams, decking of storey buildings, supporting lodging banana and plantain, building thatched houses. It is widely used by raffia palm wine tappers as ladder for climbing in some localities, used as improvised television pole. The leaves are sources of organic manure while when dried, it is used in rural households as fuel wood [8]. Sale of Bamboo generates income used to improve standard of living of rural people which significantly reduces rural poverty. Poverty has turned out to be a siege on humanity reducing the dignity and peace of man. Poverty in Nigeria is severe and widespread. It is highest in the rural areas [9].

Over the years, as a result of the increasing level of poverty, the Nigeria rural sector has been regarded as the backward sector of the economy. A vast majority of the inhabitant's rural communities are suffering from adverse environment, unemployment, poverty and disease. Rural poverty is undesirable. For millions of Nigerians rural inhabitants, life is neither satisfying nor decent. Their incomes are low, diets are inadequate, and often uncertain [10]. Hardship renders many of them redundant; malnutrition and hunger threaten their existence and survival [11]. In view of all these problems, it is important that forest exploitation/Bamboo exploitation should be done wisely to ensure its sustainability. It is however unfortunate that Bamboo resources utilization in support of rural livelihood has been characterized by abuse and misuse [12]. Wise use of this resource is closely related with food security, energy needs poverty alleviation and environmental protection. Unfortunately, most Bamboos harvested are at a rate which exceeds natural growth, so current utilization is anything, but sustainable [13], [14], Over-exploitation associated with growing human populations, destruction of tropical forests and new demand for industrial uses, especially by the pulp and paper industry, has resulted in wide-scale decimation of Bamboo stocks, from vast forests bamboo in South and Southeast Asia at the beginning of $20^{\text {th }}$ century. The greatest losses are borne by the poor, especially the rural poor, as once abundant and cheap material that provided sustenance, shelter, and income has become scarce and expensive. Truly, the present crisis in the availability of bamboo is testament to its remarkable utility [15] and [16].

Consistent increase in use pressure on Bamboo vulgaris, if unchecked could threaten the existence of the species. In this regard sources of pressure on its population need to be identified, its economic impact on the livelihood of the people and measures to mitigate its extinction. Bamboo is a resource that is closely related with food security if sold, source of energy, poverty alleviation and environmental protection. Little attention was paid to it in the past, because it was seen as not having substantial benefits in terms of generating revenue. This assumption has changed because people now realize that with proper management techniques, bamboo could be sustaining to the economy. Bamboo as a non-timber forest material can replace or use as an improvised alternative for furniture, building material, paper, ladder etc. it is a strong and reliable material for construction of scaffold by architects. The scaffold is used in building [17].

Bamboo is regarded as poor mans timber and plays a vital role in the socio-economic livelihood of the rural population [18]. Since time immemorial in human society, it contributes to the subsistence need of over a billion people worldwide [19]. Traditionally, it is used as fuel wood, rural housing (thatched house), Shelter belt, fencing, chair and various other purposes [20]. In modern days, it is used as industrial raw material for pulp and paper. Ready market exists for bamboo in the construction industry. Farmers in the yam cultivating areas of Nigeria, have high demand for Bamboo for staking vines of yams. Along the riverine areas of Nigeria, houses are built entirely with Bamboo with only raffia palm used for roffing [21]. It is source of income to the rural villages and farmers. Bamboos are plant of global interest because of their distinctive life form, their ecological importance and the wide range of uses and values to humans [22]. Above all, it is used in, making handicrafts, props for banana and plantain.

Through new techniques, Bamboo has been combined with modern materials like reinforced concrete including housing, bridges and observation towers. These architects have made a deliberate attempt to increase social acceptance of bamboo and promote its adoption as an inexpensive and environmentally friendly building materials among both the rich and the poor [23]. Bamboo are a significant structural component of many forest ecosystems and play a major role in ecosystem dynamics through their distinctive cycle of mass flowering and subsequent die - off [24]. Bamboo is fire resistant and because it can regenerate quickly, it is possible then to imagine that the rotten leaves and steams add humus to the soil and could be principal sources of mulch for maintaining and improving soil fertility [25]. In the urban and rural areas, restaurants are usually constructed with 
bamboo to enhance their beauty in some five star hotels like Sheraton; NICON Hilton Abuja, Nigeria, Bamboos are used as ornamentals. Bamboo is an exquisite component of landscape design. For the human environment, Bamboo provides shade, acts as windbreaks, provides a aesthetic value, has anti-erosion property that sticks the soil together along fragile river banks of deforested areas and in places vulnerable to erosion menace. The litter (Leaves) make fodder for animals. Bamboo is mystical. It is planted as a symbol of strength, flexibility, tenacity, endurance and compromise, and has for centuries been integral to religious ceremonies arts music and daily life. In the music industry it acts as flute or xylophone which creates some of the most beautiful sounds in music.

\section{Methodology}

The study was carried out in Mbaise, Imo State Southeast Nigeria. Mbaise is a large area of three Large Local Government areas namely: Aboh Ahiazu and Ezinihitte Local Government Areas. It is located in the rain forest area and is densely populated with a population estimate of 1 million people [28]. It is bounded in the North by Ehime Mbano, in the South by Isiala Ngwa in Abia State, in the East by Obowo and in the West by Owerri North and Ngor Okpuala LGA's. the people are great farmers producing farm / agricultural produce like yams, cassava, maize, palm oil, plantain, vegetables, Livestock, poultry, fish etc. the people have rich cultural heritage. Mbaise is bounded by latitude $5^{0} 25$ and $5^{0} 45 \mathrm{~N}$ and longitudes $6^{0} 58$ and $7^{0} 10 \mathrm{E}$ [29]. Two distinct seasons are identified - rainy (wet) and dry season. Most of the mean annual rainfall of about $2152 \mathrm{~mm}$ occurs during the wet season, April to October, and is associated with moisture - laden maritime southwest rain bearing winds from the Atlantic Ocean. The temperature ranges between $23^{\circ} \mathrm{c}$ to $26^{\circ} \mathrm{c}$ which creates an annual relative humidity of $75 \%$ with humidity reaching $90 \%$ in the rainy season. There is a period of dry spell called, "August break" which last for one week. The dry season experiences two months Harmattan from December to late February. The hottest months are between January and [30]. The people of Mbaise are highly educated which makes education the highest industry of the people. Respondents for the study were chosen from the three Local Government Areas. Random and purposive sampling techniques were used to select respondents. Three (3) communities were randomly selected from each local government area (LGA) to get Nine (9) communities. From the nine communities, twenty (20) respondents were selected on purposive basis from a list submitted by the community leader from each LGA. The sample size is one hundred and eight (180) respondents for the study. The data for the study were collected using questionnaire, oral interview schedule and field visits. The data were analyzed using percentages, return on investment frequency distribution table.

\section{Results and Discussion}

\subsection{Socio-Economic Characteristics of Respondents}

Table shows that $78 \%$ of the respondents are males while $22 \%$ are females. The same table shows that $8.99 \%$ of the respondents are within $21-30$ years, $26.67 \%$ are $31-40$ years of age, $57.78 \%$ are 51 years of age and above while 6.67 falls within 41-50 years. Analysis shows that $24 \%$ of the respondents are single while $76 \%$ are married. Table 1 equally shows that $37.78 \%$ have educational qualification of First School Leaving certificate. $35.56 \%$ O'Level, (WAEC/GCE/NABTEB), $8.89 \%$ OND, 2.22\% have Higher National Diploma (HND), 13.33\% B.Sc and other degree while $2.2 \%$ have no formal education.

Table 1. Distribution of Respondents according to socio-Economic characteristics

\begin{tabular}{lll}
\hline Sex & Frequency & Percentage (\%) \\
\hline Male & 140 & 78 \\
Female & 40 & 22 \\
Total & 180 & 100 \\
Age & & \\
$21-30$ & 16 & 8.88 \\
$31-40$ & 48 & 26.67 \\
$41-50$ & 12 & 6.67 \\
51 and above & 104 & 57.78 \\
Total & 180 & 100.0 \\
Marital status & & \\
Single & 44 & 24 \\
Married & 136 & 76 \\
Total & 180 & 100 \\
Qualification & & \\
FSLC & 68 & 37.78 \\
O'Level & 64 & 35.56 \\
OND & 16 & 8.89 \\
HND & 4 & 2.22 \\
B.Sc & 24 & 13.33 \\
No formal Education & 4 & 2.22 \\
Total & 180 & 100 \\
\hline
\end{tabular}

Source: field data, 2014

\subsection{Various Uses of Bamboo (Bambusa vulgaris)}

Table 2. Distribution of Respondents according to the various uses they made of Bamboo.

\begin{tabular}{ll}
\hline Bamboo uses & Number of users \\
\hline Staking of yam & 130 \\
Erosion control & 164 \\
Watershed & 168 \\
Architectural building/construction & 108 \\
Aesthetic decoration & 68 \\
Fuel wood & 68 \\
Local furniture making & 140 \\
Construction of platform/pallet for goats & 26 \\
Thatching/fencing & 148 \\
Barn construction & 168 \\
\hline
\end{tabular}

Sources: field data 2014

The various uses of Bamboo (Bambusa vulgaris) were shown in table 2. From the analysis, 130, 164, 168 and 68 
indicated using Bamboo for staking of yam, erosion control, watershed, and fuel wood respectively. 108 pointed out using it for building construction while 140 indicated using it for local furniture making. Equally, 68, 148 and 168 indicated using it as aesthetics, thatching and barn construction. An insignificant number (26) indicated using it for construction of pallet/platform for goats. Apart from these bamboo helps to maintain ecosystem balance such as clean air through carbon sequestration, as well as maintenance of biodiversity and attractive landscape.

\subsection{Multiple Responses: Dealers on Bamboo}

Majority of the dealers (132) or 73\% are owner dealers. They sell to middlemen who buy and supply to end users for building construction (decking of houses/storey building), especially in urban areas where they are extensively used for architectural construction. The middlemen are into full time business as they invade the rural area and buy these materials in large quantities and supply to builders. Also 36 or $20 \%$ of dealers buy from Bamboo owners and sell to yam farmers for staking of yam. $12 \%$ or $7 \%$ of the respondents supply to people who use it for thatching residential fencing and barn construction.

Table 3. Distribution of respondents dealers According to uses of bamboo

\begin{tabular}{lll}
\hline Attribute & Frequency & Percentage (\%) \\
\hline $\begin{array}{l}\text { Owner dealers who sell to } \\
\text { middlemen who purchase and resell } \\
\text { to builders }\end{array}$ & 132 & 73 \\
$\begin{array}{l}\text { Middlemen who sell to end users for } \\
\text { thatching, fencing and barn } \\
\text { construction }\end{array}$ & 12 & 7 \\
$\begin{array}{l}\text { Middle men who sell to yam } \\
\text { farmers for yam staking }\end{array}$ & 36 & 20 \\
Total & 180 & 100 \\
\hline
\end{tabular}

Source: field data, 2014.

Return on investment on bamboo accruable to dealers: It can be seen from investment analysis that investment on bamboo has a high return as much timber forest products can yield. This obviously revealed that dealers on bamboo made $92 \mathrm{k}$ and $82 \mathrm{k}$ profit from every Naira investment in the business of supply for building and staking of yams. The amount from supply for building is higher because it is an all season business while yam staking is season barred. Return on fencing, Barn construction and thatching of $76 \mathrm{k}$ is low because these activities are equally seasonal. From the foregoing, Bamboo Contributes in no small measures to employment and income generation to producers and dealers (Middlemen) in both rural and urban areas.

Table 4. Table return on Bamboo Investment

\begin{tabular}{ll|l}
\hline Attribute & ROI for Dealers & ROI f or Middlemen \\
\hline Owner dealer & 90.51 & 70.09 \\
Major Middlemen & 81.53 & 52.60 \\
Minor Middlemen & 76.24 & 90.38 \\
\hline
\end{tabular}

Source: Field survey 2014

\section{Conclusion}

Based on the result of the findings, Bamboo plant and its products have made significant contribution to the socioeconomic well being of Mbaise people. Bamboo is the fastest growing wood like substance on the planet. There is growing consensus that non-Timber forest products are not only crucial to ecosystem but also invaluable in Mbaise and environ. Bamboo is extensively used in the study area for yam staking, fencing, architectural building, construction of yam barns etc. As a result of the increasing demand, more lands should be made available for Bamboo Planting. This can be done in marginal soils that may not support growing of arable crops.

\section{References}

[1] Kigomo, B. (2007): guideline for growing Bamboo, Kenya Forestry Research Institute, KEERI pp 45.

[2] Abd. Latif, M (1993) Effects of age and height of three Bamboo species on their machining properties. Journal of tropical forest science 5 (4): 528-525,000.

[3] UN (1972): Sharing experiences of incentive measure for conservation on biological diversity, third meeting Beunos Aires.

[4] Lee, A.W.C, B. Xuesong and N.P Perry (1994) selected physical and mechanical properties of giant timber Bamboo grown in South Carolina. Forest production journal 44 (9): 40-46.

[5] RMRDC (2004); Bamboo occurrence and utilization in Nigeria Raw Materials Research and Development Council Publication, 1994.

[6] Balakrishman Nair, N (1990) forward. In Bamboos current Research (I.V. Ramanuja Rao; R. Gnanabaran and C.B. Sastry, Eds). Proceeding of the International Bamboo Workshop held in Cochin, India from Nov. 14-18, 1988. Pp viii.

[7] Ibe, A. E (2013): sustainable forest Resources management for Rural Livelihood and food security in Imo State, Nigeria. In: research for Development (R4D) Responses to Food security and Poverty reduction in Africa. A festschrift: Chigozie Cyril Asiabaka Braima D. Jame (Eds) pp 239-252.

[8] Canagarajah, S., Ngwafor J., and Thomas S. (1997), Evolution of Poverty and Welfare in Nigeria; 1985-1992, World Bank Policy Research working Papers 1715 Washington D.C. pp 23.

[9] Canagarajah, S., Ngwafor J., and Thomas S. (1997), Evolution of Poverty and Welfare in Nigeria; 1985-1992, World Bank Policy Research working Papers 1715 Washington D.C. pp 23.

[10] Ikojo, H. A. (2001). The Role of Forestry in Ameliorating Environmental Problems in Rural Communities in Nigeria. In: Popoola, L., Abu, J. E and Oni P. I. (Eds) Proceedings of the $27^{\text {th }}$ Annual Conference of Forestry Association of Nigeria held at Abuja, FTC between $17^{\text {th }}-21^{\text {st }}$ September, 2001 pp 116-128

[11] Ibe, A. E (2013): sustainable forest Resources management for Rural Livelihood and food security in Imo State, Nigeria. In: research for Development (R4D) Responses to Food security and Poverty reduction in Africa. A festschrift: Chigozie Cyril Asiabaka Braima D. Jame (Eds) pp 239-252. 
[12] Ibe, A. E (2013): sustainable forest Resources management for Rural Livelihood and food security in Imo State, Nigeria. In: research for Development (R4D) Responses to Food security and Poverty reduction in Africa. A festschrift: Chigozie Cyril Asiabaka Braima D. Jame (Eds) pp 239-252.

[13] IFAR/INBAR (1991). Research needs for Bamboo and rattan in the year 2000. Tropical tree crops Program. International Fund for Agricultural Research/International Network for bamboo and Rattan Singapore. (IFAR / INBAR, 199, Tawari, 1992),

[14] Tewari, D.N. (1997): A monograph on Bamboo. International book distribution Dehra dun (India).

[15] Sastry C.B. and Webb, D. (1990) Preface in Bamboos current research (iV. Ramanuja Rao, R Gnanabaran and C.B Sastory, pds). Proceeding of the international Bamboo workshop held in Cochin. India Nov. 14-18, 1988.. pp ix-x

[16] Kwiyamba, S. (2005): Bamboo trade and Poverty alleviation in Ileje district pp Media Ltd pp 3

[17] Okafor, J.C. Omoridon and P.S Amaza (1994) Non-Timber forestry Products: Tropical Forestry Action Programme Study Report pp 185.

[18] Prasad, R. (1990) bamboo (dendiocalanusstrictus) resources of the outer himalayasand siveliks of western utter Pradesh; a conservation plea for habitat restoration, ln bamboo current research (1, V, Ramanuja Rao. R Ganabaran and C. B Sastry, (els). Proceedings of the international, Bamboo Workshop held in Cochin lndia Nov, 14- 181988 pp 3438

[19] Raizda, J.S. (1986): Preservation treatment of green Bamboos under low Pneumatic pressure treatment pp 21.
[20] Sharma, S.N. and M.I Medra (1980). Varistin of specific gravity and tangential shrinkage in the wall thickness ofbamboo and its possible influence on trend of the shrinkage moisture content characteristics. Ind for Bull 259.

[21] Clark, L (1997): Bamboos: the centre piece of the grass family. In Chepman, G.P (Eals): the Bamboos, Linnean Society symposium series Number 19, Academic Press London, UK pp 501-512.

[22] Guitirrez, J. (2000): The development of non-traditional Bamboo technologies in Costa Rica" pp 2-6.

[23] Keeley, C.N. and Bond, I.D (1999): Agro forestry in the content of Land cleaning and conservation. Academy of Science.

[24] INBAR (2000): the Tropical tree crops and their uses. International Network Research.

[25] Limon W (1992): the Microscopic examination of woody material. Waston and microscope record number 30 .

[26] National Population Commission (NPC) (2006). Provisional census Figure 2006 Nigeria census

[27] Acholonu Alex, D.W. (2008). Water quality studies of Nworie River in Owerri, Nigeria' Mississippi Academy of science. Retrieved 2014-9-11.

[28] Monanu S. and Inyang, F (1975) Climatic regimes. In" Nigeria maps G.E.K Ofomata (Ed) 29-229. Ethiope Publishers House Benin. 